\title{
Extending the Economic Foundations of Entrepreneurship Research
}

DOI:

10.1111/emre.12158

\section{Document Version}

Accepted author manuscript

Link to publication record in Manchester Research Explorer

\section{Citation for published version (APA):}

Mccaffrey, M. (2017). Extending the Economic Foundations of Entrepreneurship Research. European Management Review. https://doi.org/10.1111/emre.12158

\section{Published in:}

European Management Review

\section{Citing this paper}

Please note that where the full-text provided on Manchester Research Explorer is the Author Accepted Manuscript or Proof version this may differ from the final Published version. If citing, it is advised that you check and use the publisher's definitive version.

\section{General rights}

Copyright and moral rights for the publications made accessible in the Research Explorer are retained by the authors and/or other copyright owners and it is a condition of accessing publications that users recognise and abide by the legal requirements associated with these rights.

\section{Takedown policy}

If you believe that this document breaches copyright please refer to the University of Manchester's Takedown Procedures [http://man.ac.uk/04Y6Bo] or contact uml.scholarlycommunications@manchester.ac.uk providing relevant details, so we can investigate your claim.

\section{OPEN ACCESS}




\title{
Extending the Economic Foundations of Entrepreneurship Research
}

Running Title: The Economic Foundations of Entrepreneurship

\section{Matthew McCaffrey}

\begin{abstract}
As the entrepreneurship discipline grows, it increasingly faces unique research challenges. Recently, "interactive, activity based, cognitively hot, compassionate, and prosocial" approaches to the study of entrepreneurship have arisen to meet these challenges. This paper reflects and builds on recent discussions by emphasizing, in addition, the persistent value of economic foundations for a progressive research agenda in entrepreneurship. A realist economic perspective is both fundamental for entrepreneurship and complements newer research trends. It has also stood the test of time: economic questions relating to methodological individualism, uncertainty, judgment, opportunities, social motivations, and incentives have not only set the tone for past research, but continue to offer starting points and insights for contemporary work. This note thus makes two contributions: first, it explains the relevance of each of these concepts for contemporary work in entrepreneurship studies, and second, it uses them to pose novel research questions. These questions complement the abovementioned emerging trends in entrepreneurship.
\end{abstract}

Keywords: economics, methodological individualism, uncertainty, judgment, opportunities, social enterprise 


\section{Extending the Economic Foundations of Entrepreneurship Research}

\section{Introduction}

As the entrepreneurship discipline grows, it increasingly faces unique research challenges. In order to meet them, the literature proposes new perspectives and further research questions. For example, Dean Shepherd's article "Party On!" outlines an ambitious research program for entrepreneurship studies that speaks to its special expertise as well as its special problems (Shepherd, 2015). Shepherd's proposals are based on a simple claim: if entrepreneurship is to continue to thrive, it must remain open to new research questions, theories, and methods, and must be willing to shift its boundaries. This means not only generating fresh ideas within the discipline, but also reaching outside it to the sciences and humanities for inspiration. For example, psychology currently plays a prominent role in entrepreneurship, but there are many additional fields of inquiry worth exploring as well. More specifically, Shepherd argues that work on "interactive, activity based, cognitively hot, compassionate, and prosocial" topics will do the most to help the discipline to grow and evolve in the coming years (Shepherd, 2015). The expanding influence of these approaches is unquestionable. Research relying on them has already proven the ability to add new insight to the literature, and there is every likelihood it will continue to do so. However, while emerging trends do offer essential guidance for the future of entrepreneurship, there is also much inspiration to be had by reflecting on the origins and fundamental questions of the discipline.

With this reflection in mind, I argue two major points: first, economic questions, concepts, and perspectives are vital drivers of new work in entrepreneurship, and offer substantial value-added to researchers of all backgrounds. Second, in addition to being useful in their own right, economic theories complement the specific research paths that Shepherd 
outlines. To show this, I pose a number of original research questions that extend a realist economic analysis of entrepreneurship, and link them to emerging research trends. My goal is not to propose a replacement for these trends, but to emphasize a complementary agenda focusing on a fundamentals-based, interdisciplinary understanding of the entrepreneurial process. I doubt many entrepreneurship scholars would dismiss economic issues as unimportant, so my objective is to show how they already underpin and expand on the kind of trends Shepherd identifies. I suggest that some economic perspectives or questions are inevitable in entrepreneurship research, and deserve persistent attention. I hope to convince researchers that a successful, forward-looking, and truly entrepreneurial discipline should be willing to return to its foundations as well as venture out past its boundaries.

The paper proceeds as follows: I first clarify the relevance of economic ideas for contemporary entrepreneurship, and explain how economists have long pursued a research agenda relevant to and supportive of activity-based and prosocial entrepreneurship. Naturally, these topics intersect and overlap to some extent, and the different sections are not fully compartmentalized; rather, they reflect the many interwoven strands of inquiry that comprise entrepreneurship research and practice. Therefore although my discussion invokes Shepherd's (2015) specific analysis, it applies to a wide range of other entrepreneurship research as well. In order to be concise, throughout this paper I assume some familiarity with emerging research agendas in entrepreneurship. What follows is not then a survey of all economic writings relevant to entrepreneurship, or even a summary of recent contributions (e.g. Parker, 2005; Minniti and Lévesque, 2008). Instead, I reflect on several different ways that core economic questions can and should influence entrepreneurship's evolving agenda. I explain that a realist economic perspective can resolve or avoid problems in entrepreneurship research, as well as encourage useful new research questions. 


\section{Economic Foundations of Entrepreneurship Research}

Entrepreneurship has been recognized as a distinct field of study for several decades, but its research agenda also has a long history of engagement with economic questions, and the two types of inquiry are highly complementary. It is not a coincidence, for example, that the term "entrepreneur" was popularized by an economist, Jean-Baptiste Say (Hoselitz, 1960), or that Mark Casson's classic book The Entrepreneur, which deeply influenced the founding of the modern discipline, is subtitled "An Economic Theory" (Casson, 1982). Yet despite this interdisciplinary influence, it is not always obvious how economics and entrepreneurship relate to each other in the modern era, especially because entrepreneurship remains a relatively neglected topic among mainstream economists. Nevertheless, although entrepreneurship has established its own identity and engages in original research, in many ways it remains motivated by and engaged with certain types of economic questions (Minniti and Lévesque, 2008).

The most obvious examples are the theoretical frameworks that have played large roles in entrepreneurship research since the founding of the modern discipline. From the earliest days, the theories of economists like Joseph Schumpeter, Frank Knight, and Israel Kirzner have often been considered especially useful for stimulating important research questions, and in many ways defined them. Each of these approaches is grounded in distinctly economic problems: Schumpeter sought to explain the riddle of economic growth in a general equilibrium context (Schumpeter, 1934); Knight's theory is an answer to the question of the source of entrepreneurial profit (Knight, 1933 [1921]); and Kirzner's theory of alertness attempts to use "pure" theory to explain market clearing and equilibration (Kirzner, 1973).

However, although their original motivations have been mostly forgotten, each of these "system-level" approaches (McMullen and Shepherd, 2006) continues to be applied to 
problems in modern entrepreneurship: Schumpeter inspired interest in entrepreneurship as innovation (Baumol, 1993), Knight highlighted the role of uncertainty in entrepreneurial decision-making (Foss and Klein, 2012), and Kirzner influenced the definition of entrepreneurship as the study of opportunities (Shane and Venkataraman, 2000). Their legacies remain relevant even though entrepreneurship has changed significantly over the last few decades. Moreover, through careful application, economic insights can be extended beyond the system-level theories mentioned above. In fact, they frequently dovetail with recent research trends, which often turn out to be engaging the same questions posed by economists a century or more ago.

Unfortunately, although economics is one parent of entrepreneurship, it continues to have a somewhat dysfunctional relationship with its offspring. Scholars have long complained of the absence of entrepreneurship research in mainstream economics (Baumol, $1968,1993,2006)$ even though its influence in management, the social sciences, and the humanities is growing by leaps and bounds. The reason is that mainstream economic thinking continues to focus on the formal modeling of behavior in equilibrium contexts where problems can be conceptualized using highly simplified and generally unrealistic assumptions about value, choice, uncertainty, and a wide range of other issues germane to entrepreneurship. However, entrepreneurship theory can and should take a "realist" approach; that is, describe entrepreneurial action as it occurs in a complex and uncertain world, rather than attempt to model it under ideal conditions that assume away these vital problems. The kind of reasoning discussed in this paper therefore falls largely outside the economic mainstream. As a result, even though the argument sometimes mentions "economics" in a general sense, this term is shorthand for its more entrepreneurial branches that are often considered out-of-step with current orthodoxy. Although there are many economic definitions of entrepreneurship (Hébert and Link, 1988), this paper emphasizes the Knightian strand 
along with some similar approaches. In fact, several of the following sections involve teasing out a series of core concepts from this definition in light of current research. In particular, I draw on the "causal-realist" approach to economics associated with the Austrian school of thought (e.g. Klein, 2008b). Both parts of this approach — an interest in causal relations and an emphasis on realism — have an important role to play in entrepreneurship studies. The question of realism is especially relevant, and so where necessary, for the sake of clarity, I also distinguish between mainstream and realist economics.

Despite ongoing tension between the more and less entrepreneurial strands of economics, the latter do offer a rich understanding of entrepreneurial processes in their myriad forms. Certainly their insights extend beyond narrow problems like self-employment or risk aversion, which sometimes define entrepreneurship in mainstream theory (e.g. Kihlstrom and Laffont, 1979; Lazear, 2004). In any case, contemporary entrepreneurship can benefit from taking realist economic ideas and research questions seriously. I now consider several directions these collaborations might take, and situate them in relation to more recent research trends. This list is by no means exhaustive; instead, I will expand on a few central points of interest to both economists and entrepreneurship scholars, as a way to encourage both to reconsider their common ground.

\section{Methodological Individualism}

Activity based, processual entrepreneurship research implicitly takes the individual actor as a starting point. In this sense, it is supported by the economic notion of “methodological individualism." Appropriately, this term was coined by Schumpeter (2010 [1908]), although his later work on entrepreneurship took the idea to an extreme through its emphasis on the individual innovator, to the exclusion of team or community action (Schumpeter, 1942; Harper, 2008). However, methodological individualism does not mean 
that only individuals are worth studying; instead, it recognizes the primacy of individual actions. These actions take on added significance in group or team contexts, but never disappear completely (Casson, 2015, 1982, p. 23; Casson and Casson, 2013, p. 8).

Economic and entrepreneurial groups or teams (Harper, 2008; Ruef, 2010) are made up of individuals and their distinct actions and psychological attributes, e.g. individuals' choices, knowledge, and cognitive processes (Busenitz and Barney, 1997; Gregoire, Barr, and Shepherd, 2010), the investigation of which has spawned an enormous and varied literature (Mitchell et al., 2007). Although there is sometimes tension between system-level and individual-level theories (McMullen and Shepherd, 2006), the economic theory of entrepreneurship as judgment (discussed below) brings both views into harmony (Casson, 2015; Knight, 1942). Through individual actions we make sense of larger processes and effects, such as how entrepreneurship transforms communities, and vice versa. When studying "the embodiment of knowledge between an entrepreneur and a community" (Shepherd, 2015), we inevitably make reference to individual minds, which are the foundations of action and process, and especially, of how actions and processes are interpreted by entrepreneurs and researchers.

Methodological individualism thus leads to a "deeper understanding of how potential opportunities are developed and refined" (Shepherd, 2015). For example, if it is correct that opportunities do not exist exclusively in either the mind or the outside world, but are interrelated and appear in both, then surely the individual mind must play a role in shaping the non-individual external environment. That environment in turn constantly encourages the individual mind to revise its beliefs about potential opportunities. This view offers a middle ground between proponents of opportunity-based theories and their critics (discussed below). By focusing on individual minds, we can analyze opportunities in more realistic ways and avoid further confusing the issue by anthropomorphizing them (McCaffrey, 2014a). 


\section{Uncertainty}

Entrepreneurship research maintains a strong interest in the role of uncertainty in entrepreneurial decision-making. In fact, uncertainty has been a defining characteristic of entrepreneurship since Richard Cantillon published the first treatise on economics almost three centuries ago (Cantillon, 2001 [1755]). Today, drawing on Frank Knight's influential distinction between risk and uncertainty (Knight, 1933 [1921]), new literature continues to explore the meaning of uncertainty, how it shapes entrepreneurs' perceptions, doubts, and knowledge, and how actors can ultimately overcome it (McMullen and Shepherd, 2006). Uncertainty is a fundamental concept for activity-based entrepreneurship research because it reflects the environment in which action occurs. In particular, it implies that entrepreneurship is a process taking place through time, as opposed to a static choice or mindset (McMullen and Dimov, 2013). Entrepreneurs take time into account in forming their beliefs and doubts about opportunities, and consequently, if and how to exploit them.

Despite the conceptual importance of uncertainty, however, there is a notable lack of research on its nature, types, and time horizons (Bloom, 2014). This then is an area in need of further investigation. There are numerous questions concerning uncertainty that are worth exploring from a realist economic perspective, especially regarding the quantity and quality of uncertainty. For example: are current conceptualizations and typologies of uncertainty sufficient (Dequech, 2011), and are they based on appropriate assumptions about quantification and probability (Tarko, 2013)? Is it correct that uncertainty is not quantifiable, as many theorists have suggested (Knight, 1933 [1921]; Mises, 1998 [1949])? How does entrepreneurial performance change under conditions of risk versus uncertainty (Burns et al., 2016)? Do entrepreneurs perceive different types of uncertainty? If so, are there types that entrepreneurs are unable to bear, such as political uncertainty (Higgs, 1997; Wiśniewski, 2012)? Or are different types of entrepreneurship suited to specific types of uncertainty 
(Williams and Vorley, 2015)? These economic questions represent key steps in our effort to understand entrepreneurial doubt, error, and successful action. Combined with judgmental decision-making, uncertainty is the root of an activity-based entrepreneurship.

\section{Action and Judgmental Decision-Making}

Building on the notion of uncertainty, realist economics offers a wide range of accounts of entrepreneurial action. I pay special attention to writers like Frank Fetter (1915), Frank Knight (1933 [1921]), and Ludwig von Mises (1998 [1949], 2008 [1951]), who stressed the importance of entrepreneurial judgment about the use of heterogeneous scarce resources in the market process. Today, judgment of uncertain conditions continues to be a defining characteristic of entrepreneurial action (McMullen and Shepherd, 2006; Foss and Klein, 2012, 2015; Klein, 2008a), as well as a valuable tool for discussing public policy (McCaffrey, 2015). Most importantly, it lies at the heart of the activity-based approach.

A good example is economists' interest in the economic and social functions of entrepreneurship. Rather than study entrepreneurship as an occupation, personality, or type of firm, functional or system-level theories of entrepreneurship view it as a series of actions, or a process (Klein, 2008a). These theories focus "less on the single act of exploiting an opportunity and more on the series of activities involved in the emergence of a new firm" (Shepherd, 2015; emphasis in original). In this way, they are already promoting the kind of activity-based, processual research appearing in entrepreneurship studies.

Some of the most important questions that functional theories ask involve causal relations in entrepreneurship. For instance, to what extent do entrepreneurs cause or create profitable opportunities? Can this causation be reversed? That is, is it possible that profitable opportunities cause themselves to be noticed (Kirzner, 1982, 1985)? Or is it more plausible that entrepreneurs use strong judgmental decision-making to carry out their venture ideas 
(McCaffrey, 2014a, 2015)? What are the implications of judgment for investment (Huang and Pearce, 2015)? How do judgments evolve in the face of changing experience and knowledge (Uygur and Kim, 2016)? And how much entrepreneurial success (failure) can be attributed to good (bad) decision-making rather than random chance, or luck (Foss and Klein, 2015)? What role do entrepreneurs play in making rather than taking market prices? How do entrepreneurs form their judgments in non-price contexts, such as charitable work or social enterprise (McCaffrey, 2018)? Are economic factors necessary for entrepreneurs to effectively allocate resources outside the price system? For example, can economic theory explain how public organizations behave entrepreneurially, or fail to (Klein et al., 2010)?

\section{Opportunity}

Questions about the entrepreneur's economic function lead naturally to the ongoing debate about the use of the opportunity construct in entrepreneurship. Following works like Shane and Venkataraman (2000) and Shane (2003), entrepreneurship is usually defined with respect to opportunities. Yet this concept has proven notoriously difficult to elucidate (Dimov, 2011), and numerous debates about the ontological status of opportunities continue to populate the literature (Ramoglou and Tsang, 2016). A recent essay even argues that the dispute between the "discovery" and "creation" views amounts to theoretical "fetishism" (Crawford, Dimov, and McKelvey, 2016). In fact, there are so many inconsistent and conflicting views of opportunity that some research argues the construct should be discarded altogether, and a new defining concept chosen to replace it (Davidsson and Tonelli, 2013; Davidsson, 2003, 2015; Klein and Foss, 2008).

This debate highlights the importance of a realist economic approach to entrepreneurship, which avoids the ontological quagmire of opportunities by focusing on concrete individual actions. In other words, by taking action as the unit of analysis and 
process as its logical result, defining opportunities in a universally consistent way becomes unnecessary. Instead of trying to match an observed entrepreneurial activity with an elusive academic definition of opportunity, research can instead focus on concrete behavior and its consequences, for example, how entrepreneurs combine heterogeneous capital assets (Chiles et al., 2010). An action-based and forward-looking approach avoids treating entrepreneurship as a deterministic result of antecedent factors (McMullen and Dimov, 2013), and opens the way for richer discussions of uncertainty, doubt, and error (McMullen and Shepherd, 2006). It also encourages further research into distinct actions and decisions within the entrepreneurial process. This allows us to better disaggregate each stage of that process, and also to avoid overemphasizing some stages (such as the antecedents of action), or consigning them to a black box that spontaneously opens prior to "real" activity (McMullen and Dimov, 2013; McCaffrey, 2014a).

\section{Economic Value and Prosocial Motivations}

Realist economic theories of entrepreneurship are not concerned only with narrowly self-interested behavior, and need not avoid questions about prosocial action. In fact, they can provide a valuable starting point for research on social venturing. Unlike the ways it is sometimes modeled in mainstream economics (Kihlstrom and Laffont, 1979; Lazear, 2004), entrepreneurial behavior in more traditional economic theory is more than self-employment: it is a foundation and "driving force" of social change, to use the phrase of Ludwig von Mises (Mises, 1998 [1949]). Even profit-seeking entrepreneurship is profoundly social in nature, in that it establishes a basis for mutually-beneficial exchange and cooperation within the division of labor (Salerno, 1990; Bylund, 2016, pp. 26-27, 34; McCaffrey, 2018). The constant entrepreneurial struggle to satisfy consumers improves social welfare and ensures the efficient allocation of resources. In this sense, entrepreneurship has been viewed as social since before even Adam Smith. A corollary to this view is the claim that undermining 
entrepreneurial processes - for example, through poorly-designed public policies — is antisocial in that it breaks bonds of trust and mutual interest, and erodes the foundations of growth. Entrepreneurship is therefore a much larger phenomenon with more revolutionary implications than, for instance, the founding of an isolated business venture (which can already be quite socially disruptive). It is also difficult if not impossible to discuss without considering its greater social significance, as entrepreneurship is in this sense economically embedded. In turn, analyzing entrepreneurship requires something like a realist economic view_ one that takes context, complexity, and uncertainty into account.

Yet entrepreneurship is also social in the more modern, cognitive sense used in entrepreneurship studies. The economic function of the entrepreneur is to bear uncertainty by making judgments about how best to serve the community using heterogeneous scarce resources (Foss et al., 2007). This view does not require any assumptions about profit-seeking in the monetary sense, narrow self-interest, or emotionless calculation, which are often associated with mainstream economic analyses (Miller, et al. 2012). That is, entrepreneurs can also transform, improve, and even destroy human communities for other reasons, e.g. for social and political purposes (Daskalaki, Hjorth, and Muir, 2015). It is especially important not to dismiss all economic views of action on the grounds that they must assume the selfish pursuit of monetary profit. It is true that entrepreneurial action is often motivated by the search for wealth. Nevertheless, economists who adopt the subjective, marginalist theory of value recognized long ago that human action involves the pursuit of "psychic profit" (subjective benefit) and the avoidance of "psychic loss" (subjective cost) rather than the simple acquisition of money profits (Fetter, 1915; pp. 26-29).

In fact, some even argue that the pursuit of psychic profit is a universal, entrepreneurial feature of human action (Mises, 1998 [1949]; Kirzner, 1973). Its universality means it applies to traditional economic motivations like monetary profit as well as to social 
motivations such as transforming and improving communities. Adopting the subjective, "psychological" approach as a broad framework thus allows us to use almost any conceivable motivation or emotion as a starting point for research. The entrepreneurial element in human action lets us disaggregate economic and social purposes and avoid emotional black boxes, getting at the core of heterogeneous motivations by viewing them as individual, subjective valuations. In other words, it offers a realistic view of human motivation without falling into the trap of assuming a (mainstream) "economic man," a "Robbinsian maximizer" (Kirzner, 1973, 1985), or any another mechanical model of choice.

\section{Incentives and Entrepreneurship}

It is increasingly common for popular writings to define mainstream economics as the study of incentives, and in policy discussions we are frequently reminded — if not scoldedthat "incentives matter" (e.g. Landsburg, 1993, p. 3; Levitt and Dubner, 2005, p. 20; Cowen, 2007, p. 2). Although this view may be misleading in some ways, it is certainly true that incentives are significant for most if not all types of economic theory, and it is natural that they likewise carry important implications for entrepreneurship. Incentives are also closely related to the topics discussed above. In particular, they are indispensable for considering questions of entrepreneurial motivation, as an incentive is simply another way to talk about the goals that entrepreneurs believe are most valuable (McCaffrey, 2014b). As explained in the previous section on motives, incentives are often conceived as monetary rewards or penalties, but the subjective theory of value reduces them to their most essential element, namely, the pursuit of value in a psychic sense. By doing so, it opens entrepreneurship theory to a wide range of questions about how and why entrepreneurs respond to incentives.

One of these is whether there are uniquely entrepreneurial incentives. Israel Kirzner argues this much through his theory of alertness. For Kirzner, profitable opportunities are 
"entrepreneurial incentives," that is, sources of value that cause their own discovery by switching on "the entrepreneurial antennae" (Kirzner, 1982, 1985, p. 109). For Kirzner, entrepreneurs face these and only these incentives, whereas conventional incentives - that is, objects of conscious choice that are weighed by actors - are inherently non-entrepreneurial (Kirzner, 1979, p. 148; 1985, pp. 96-97). Kirzner's view has been criticized, however, because it treats opportunities as exogenous causal forces; this results either in logical problems or in making opportunity discovery simply a matter of luck (McCaffrey, 2014a; Hülsmann, 1997). Either way, the theory provides little guidance for public policy.

In contrast to Kirzner's view, the entrepreneurship literature has focused mainly on explaining how the standard view of incentives can be applied in specifically entrepreneurial contexts. The most influential example of this approach is William Baumol's work on the relation between institutions and entrepreneurship (Baumol, 1990). Baumol shows that institutions provide fundamental incentives for entrepreneurs by establishing the relative social rewards for different kinds of talent. These include intangible rewards such as social status, access to improved networks, and political favor, in addition to simple wealth (Boettke and Piano, 2016). Understanding the range of available incentives informs entrepreneurs' judgments about which kinds of investments to pursue. As a typical example, high tax rates on entrepreneurial profits provide disincentives for entrepreneurs to search for or even stumble upon profitable opportunities (McCaffrey, 2015). In general then, "the proper way to encourage entrepreneurship is to create conditions that make entrepreneurial pursuit of selfinterest accord with societal wealth creation" (Davidsson and Wiklund, 2001). This analysis applies to compassionate venturing as well, which faces both common and unique incentives, including incentives created through public policy. It thus holds the key to larger questions in entrepreneurship, such as: "why do some [people] use entrepreneurial action to destroy value, exploit the vulnerable, and/or harm nature?” (Shepherd, 2015). Incentives, as determined by 
the institutional setup, often provide a framework with which to answer such questions (Baumol, 1990; Bylund and McCaffrey, 2017).

\section{Economics and Entrepreneurship: Gains from Trade}

Shepherd (2015) notes the danger of falling into a "competency trap" where "safe" research is rewarded over riskier work, in turn leading to narrow research interests and an inability to think in terms of the "big picture." An obvious criticism of mainstream economics is that it leads to just this problem. Critics argue that the mainstream has fallen into its own competency trap through an excessive focus on answering narrow questions of interest only to specialists (e.g. Foss and Klein, 2015). However, this criticism does not apply to realist economic work on entrepreneurship, and this research stream, though marginalized, remains vibrant and interested in the kind of "big" questions that encourage wide-ranging study rather than narrow specialization (Minniti and Lévesque, 2008). In fact, realist economics' systemlevel thinking makes it ideal for encouraging scholars to ask searching, profound questions. It also places boundaries on entrepreneurship by hinting at its limitations, for instance, its incentive or institutional constraints. Moreover, without the kind of core economic concepts discussed above, it becomes difficult to define a unique space for entrepreneurship theory and practice to explore. For these reasons I suggest that realist economics provides a "brain" for entrepreneurship research - that is, a rigorous, fundamental set of methods and conceptsjust as psychological-cognitive models can.

At the same time, the knowledge transfer between economics and entrepreneurship can run both ways. Economics is a prime example of Shepherd's point that, "using methods from other disciplines will require some adaptation, and these adaptations themselves may represent a contribution back to the original source" (Shepherd, 2015). Mainstream economists should be encouraged to take seriously the same theories and concepts they 
introduced into the academic literature, as well as to consider ideas from other disciplines. As F.A. Hayek put it, "the economist who is only an economist is likely to become a nuisance if not a positive danger" (Hayek, 1956, p. 463). After being downplayed in economics for a century or more (Johnson, 1914), it is high time for entrepreneurship to once again become an inspiration for the dismal science. To take only one example, entrepreneurship can add a much-needed element of realism to an economics profession struggling to maintain its identity and relevance a decade after the global financial crisis. By embracing a view of human behavior that takes account of error and a diversity of motivations, entrepreneurship helps to explain the real world and thus provide a "heart" for economic theory in place of abstract and mechanical models of choice. It is not unreasonable to suggest that if economists had been more willing a decade ago to study the difference between real and illusory opportunities, the difficulties posed by extreme uncertainty in financial markets, the entrepreneurial decision-making process of financial institutions and regulators, and the relevance of such processes for society generally rather than for a narrow group of stakeholders, the events of the Great Recession might have played out quite differently.

To paraphrase the old saying about political parties, economics without entrepreneurship has no heart, and entrepreneurship without economics has no brain. Economic questions are very much alive in entrepreneurship research, and help to motivate, complement, and enhance work in many areas, including interactive, activity based, cognitively hot, compassionate, and prosocial topics. In fact, I argue that we cannot truly understand many of these problems without first considering their economic foundations. This means grappling with fundamental concepts that either originate in economics or that offer a distinctly economic perspective, including — but not limited to - methodological individualism, uncertainty, judgment, opportunity, social motivation, and incentives. Yet the research questions and suggestions posed throughout this paper are only a few examples of 
how economic perspectives can develop current themes in entrepreneurship research. Many other types of work could be added to the list, and other academic disciplines brought to bear on entrepreneurial problems. Other points of past or potential common interest include the institutional foundations of different types of entrepreneurship (and their limitations) (e.g. Henrekson and Sanandaji, 2011; Bylund and McCaffrey, 2017); transaction costs and the theory of the firm (e.g. Topan, 2018); the separation of psychic and monetary profit from other forms of income (e.g. McCaffrey, 2018); inequalities in and resulting from entrepreneurial profit (e.g. Packard and Bylund, forthcoming); and the relation between action-based economic theory and cognitive-psychological models of entrepreneurial behavior (e.g. Shepherd, 2015). The task facing scholars then is to be entrepreneurial in applying and extending these concepts wherever they are valuable, which, I suggest, is a large range of topics in and around the entrepreneurship discipline. 


\section{References}

Baumol, W.J., 2006, “Textbook Entrepreneurship: Comment on Johansson.” Econ Journal Watch, 3: 133-136.

Baumol, W.J., 1993, "Formal Entrepreneurship Theory in Economics: Existence and Bounds." Journal of Business Venturing, 8: 197-210.

Baumol, W.J., 1990, "Entrepreneurship: Productive, Unproductive, and Destructive.” Journal of Political Economy, 98: 893-921.

Baumol, W.J. 1968, "Entrepreneurship in Economic Theory." American Economic Review, 58: 64-71.

Bloom, N., 2014, "Fluctuations in Uncertainty.” Journal of Economic Perspectives, 28: 153-176.

Boettke, Peter J., and Ennio Piano, 2016, “Baumol's Productive and Unproductive Entrepreneurship after 25 Years.” Journal of Entrepreneurship and Public Policy, 5: 130-144.

Burns, Barclay L., J.B. Barney, Ryan W. Angus, and Heidi N. Herrick, 2016, "Enrolling Stakeholders under Conditions of Risk and Uncertainty." Strategic Entrepreneurship Journal, 10: 96-106. 
Busenitz, L.W., and J.B. Barney, 1997, "Differences Between Entrepreneurs and Managers in Large Organizations: Biases and Heuristics in Strategic Decision Making." Journal of Business Venturing, 12: 9-30.

Bylund, Per, and McCaffrey, Matthew, 2017, “A Theory of Entrepreneurship and Institutional Uncertainty.” Journal of Business Venturing, 32: 461-475.

Bylund, Per, 2016, The Problem of Production: A New Theory of the Firm. Abingdon, UK: Routledge.

Cantillon, Richard, 2001 [1755], Essay on the Nature of Commerce in General. Trans. Henry Higgs. New Brunswick, NJ: Transaction.

Casson, Mark, and Catherine Casson, 2013, The Entrepreneur in History: From Medieval Merchant to Modern Business Leader. Basingstoke: Palgrave Macmillan.

Casson, Mark, 2015, "The Individual, the Firm and the Global Economy." Paper presented at the Reading-UNCTAD International Business Conference, Reading, 13-14 June.

Casson, Mark, 1982, The Entrepreneur: An Economic Theory. 2nd ed. Oxford: Martin Robertson.

Chiles, Todd H., Christopher S. Tuggle, Jeffery S. McMullen, Leonard Bierman, and Daniel W. Greening, 2010, "Dynamic Creation: Extending the Radical Austrian Approach to Entrepreneurship." Organization Studies, 3: 7-46. 
Cowen, Tyler, 2007, Discover Your Inner Economist: Use Incentives to Fall in Love, Survive Your Next Meeting, and Motivate Your Dentist. New York: Dutton.

Crawford, G. Christopher, Dimo Dimov, and Bill McKelvey, 2016, "Realism, Empiricism, and Fetishism in the Study of Entrepreneurship.” Journal of Management Inquiry, 25: $168-170$.

Daskalaki, Maria, Hjorth, Daniel, and Johanna Mair, 2015, “Are Entrepreneurship, Communities, and Social Transformation Related?” Journal of Management Inquiry, 24: 419-423.

Davidsson, Per and Marcello Tonelli, 2013, “Killing Our Darling: Why We Need to Let Go of the Entrepreneurial Opportunity Construct.” In Conference Proceedings: Australia Centre for Entrepreneurship (ACE) Research Exchange Conference 2013, ed.

Per Davidsson. Australia Centre for Entrepreneurship: Queensland University of Technology.

Davidsson, P. and Wiklund, J., 2001, "Levels of Analysis in Entrepreneurship Research: Current Research Practice and Suggestions for the Future.” Entrepreneurship Theory and Practice, 25: 81-100.

Davidsson, Per, 2015, “Entrepreneurial Opportunities and the Entrepreneurship Nexus: A ReConceptualization.” Journal of Business Venturing, 30: 674-695. 
Davidsson, Per, 2003, “The Domain of Entrepreneurship Research: Some Suggestions.” In J.

Katz \& D.A. Shepherd (eds.), Advances in Entrepreneurship, Firm Emergence and

Growth, Vol 6. Amsterdam: Elsevier, pp. 315-372.

Dequech, D., 2011. "Uncertainty: a Typology and Refinements of Existing Concepts." Journal of Economic Issues, 45: 621-640.

Dimov, D., 2011, “Grappling With the Unbearable Elusiveness of Entrepreneurial Opportunities.” Entrepreneurship Theory and Practice, 35: 57-81.

Fetter, Frank A, 1915, Economic Principles. New York: The Century Co.

Foss, K., N.J. Foss, P.G. Klein, and S.K. Klein, 2007, “The Entrepreneurial Organization of Heterogeneous Capital.” Journal of Management Studies, 44: 1165-1186.

Foss, Nicolai J., and Peter G. Klein, 2015, “Introduction to a Forum on the Judgment-Based Approach to Entrepreneurship: Accomplishments, Challenges, New Directions.” Journal of Institutional Economics, 11: 585-599.

Foss, Nicolai J., and Peter G. Klein, 2012, Organizing Entrepreneurial Judgment: A New Approach to the Firm. Cambridge: Cambridge University Press.

Granovetter, M.S., 1985, "Economic Action and Social Structure: The Problem of Embeddedness.” American Journal of Sociology, 91: 481-510.

Gregoire, D.A., P.S. Barr, and D.A. Shepherd, 2010, “Cognitive Processes of Opportunity Recognition: the Role of Structural Alignment.” Organization Science, 21: 413-431. 
Harper, David A., 2008, “Toward a Theory of Entrepreneurial Teams.” Journal of Business Venturing, 23: 613-626.

Hayek, F.A., 1956, “The Dilemma of Specialization,” in Leonard D. White (ed.), The State of the Social Sciences. Chicago: University of Chicago Press.

Hébert, Robert, and Albert Link, 1988, The Entrepreneur: Mainstream Views and Radical Critiques. $2^{\text {nd }}$ ed. New York: Praeger.

Henrekson, M. and Sanandaji, T., 2011, "The Interaction of Entrepreneurship and Institutions.” Journal of Institutional Economics, 7: 47-75.

Higgs, R., 1997, "Regime Uncertainty: Why the Great Depression Lasted So Long and Why Prosperity Resumed after the War.” Independent Review, 1: 561-590.

Hoselitz, Bert F., 1960, “The Early History of Entrepreneurial Theory.” In Joseph J.

Spengler and William R. Allen (eds.), Essays in Economic Thought: Aristotle to Marshall. Chicago: Rand McNally \& Company.

Huang, L., and J.L. Pearce., 2015, "Managing the Unknowable: The Effectiveness of Earlystage Investor Gut Feel in Entrepreneurial Investment Decisions.” Administrative Science Quarterly, 60: 634-670.

Hülsmann, Jörg Guido, 1997, “Knowledge, Judgment, and the Use of Property.” Review of Austrian Economics, 10: 23-48. 
Johnson, Alvin S., 1914, "Davenport's Economics and the Present Problems of Theory." Quarterly Journal of Economics, 28: 417-446.

Kihlstrom, Richard E., and Jean-Jacques Laffont, 1979, “A General Equilibrium Entrepreneurial Theory of Firm Formation Based on Risk Aversion.” Journal of Political Economy, 87: 719-748.

Kirzner, Israel M., 1985, Discovery and the Capitalist Process. Chicago: University of Chicago Press.

Kirzner, Israel M., 1982, "Competition, Regulation, and the Market Process: An "Austrian" Perspective. Cato Policy Analysis. 18.

Kirzner, Israel M.1979. Perception, Opportunity, and Profit. Chicago: University of Chicago Press.

Kirzner, Israel M., 1973, Competition and Entrepreneurship. Chicago: University of Chicago Press.

Klein, Peter G., Joseph T. Mahoney, Anita M. McGahan, and Christos N. Pitelis, 2010, “Toward a Theory of Public Entrepreneurship.” European Management Review, 7: 1-15.

Klein, Peter G., and Nicolai J. Foss, 2008, “The Unit of Analysis in Entrepreneurship Research: Opportunities or Investments?" International Journal of Entrepreneurship Education, 6: 145-70. 
Klein, P.G., 2008a, “Opportunity Discovery, Entrepreneurial Action, and Economic Organization.” Strategic Entrepreneurship Journal, 2: 175-190.

Klein, Peter G., 2008b, “The Mundane Economics of the Austrian School.” Quarterly Journal of Austrian Economics, 11: 165-187.

Knight, Frank H., 1942, "Profit and Entrepreneurial Functions.” Journal of Economic History, 2(S1): 126-132.

Knight, Frank H., 1933 [1921], Risk, Uncertainty, and Profit. Series of Reprints of Scarce Works on Political Economy No. 16. London: London School of Economics and Political Science.

Landsburg, Steven E., 1993, The Armchair Economist: Economics and Everyday Life. New York: The Free Press.

Lazear, Edward P., 2004, "Balanced Skills and Entrepreneurship." American Economic Review, 94: 208-211.

Levitt, Steven D., and Stephen J. Dubner, 2005, Freakonomics: A Rogue Economist Explores the Hidden Side of Everything. New York: Harper-Collins.

McCaffrey, Matthew, 2018, "Economic Calculation and the Limits of Social Entrepreneurship.” In Matthew McCaffrey (ed.), The Economic Theory of Costs: Foundations and New Directions. London: Routledge. 
McCaffrey, Matthew, 2015, "Economic Policy and Entrepreneurship: Alertness or Judgment?” In P. Bylund \& D. Howden (eds.) The Next Generation of Austrian Economics: Essays in Honor of Joseph T. Salerno. Auburn, AL: Ludwig von Mises Institute.

McCaffrey, Matthew, 2014a, "On the Theory of Entrepreneurial Incentives and Alertness." Entrepreneurship Theory and Practice, 38: 891-911.

McCaffrey, Matthew, 2014b, "Incentives and the Economic Point of View: The Case of Popular Economics.” Review of Social and Economic Issues. 1: 71-87.

McMullen, J.S., and D. Dimov, 2013, “Time and the Entrepreneurial Journey: The Problems and Promise of Studying Entrepreneurship as a Process. ” Journal of Management Studies, 50: 1481-1512.

McMullen, J.S., and D.A. Shepherd, 2006, "Entrepreneurial Action and the Role of Uncertainty in the Theory of the Entrepreneur." Academy of Management Review, 31: 132-152.

Miller, T.L., Grimes, M.G., McMullen, J.S. and Vogus, T.J., 2012, "Venturing for Others with Heart and Head: How Compassion Encourages Social Entrepreneurship.” Academy of Management Review, 37: 616-640.

Minniti, Maria, and Moren Lévesque, 2008, "Recent Developments in the Economics of Entrepreneurship.” Journal of Business Venturing, 23: 603-612. 
Mitchell, Ronald K., Lowell W. Busenitz, Barbara Bird, Connie Marie Gaglio, Jeffery S.

McMullen, Eric A. Morse, and J. Brock Smith, 2007, “The Central Question in Entrepreneurial Cognition Research 2007." Entrepreneurship Theory and Practice, 31: 1-27.

Mises, Ludwig von, 2008 [1951], Profit and Loss. Auburn, AL: Ludwig von Mises Institute.

Mises, Ludwig von, 1998 [1949], Human Action: Scholar's Edition. Auburn, AL: Ludwig von Mises Institute.

Packard, Mark, and Per L. Bylund, forthcoming, "On the Relationship of Inequality and Entrepreneurship.” Strategic Entrepreneurship Journal.

Parker, S.C., 2005, “The Economics of Entrepreneurship: What We Know and What We Don't." Foundations and Trends in Entrepreneurship, 1:1-54.

Ramoglou, Stratos, and Eric Tsang, 2016, “A Realist Perspective of Entrepreneurship: Opportunities as Propensities.” Academy of Management Review, 41: 410-434.

Ruef, M., 2010, The Entrepreneurial Group: Social Identities, Relations, and Collective Action. Princeton, NJ: Princeton University Press.

Salerno, Joseph T., 1990, "Ludwig von Mises as Social Rationalist." Review of Austrian Economics, 4: 26-54.

Schumpeter, Joseph A., 1942, Capitalism, Socialism, and Democracy. New York: Harper and Brothers Publishers. 
Schumpeter, Joseph A., 1934, The Theory of Economic Development. Trans. by Redvers Opie. Cambridge, MA: Harvard University Press.

Schumpeter, Joseph A., 2010 [1908], The Nature and Essence of Economic Theory. Ed. Bruce A. McDaniel. New Brunswick, NJ: Transaction.

Shane, Scott, and S. Venkataraman, 2000, “The Promise of Entrepreneurship as a Field of Research.” Academy of Management Review, 25: 217-226.

Shane, S.A., 2003, A General Theory of Entrepreneurship: The Individual-Opportunity Nexus. Edward Elgar: Cheltenham, UK.

Shepherd, D., 2015, "Party on! A Call for Entrepreneurship Research that is More Interactive, Activity Based, Cognitively Hot, Compassionate, and Prosocial.” Journal of Business Venturing, 30: 489-507.

Tarko, Vlad, 2013, “Can Probability Theory Deal with Entrepreneurship?” Review of Austrian Economics, 26: 329-345.

Topan, Mihai-Vladimir, 2018, “Austrian Economics and Transaction Cost Economics: Notes on a Doubtful Compatibility.” In Matthew McCaffrey (ed.), The Economic Theory of Costs: Foundations and New Directions. London: Routledge.

Uygur, U. and Kim, S.M., 2016, "Evolution of Entrepreneurial Judgment With VentureSpecific Experience.” Strategic Entrepreneurship Journal, 10:169-193. 
Williams N., and T. Vorley, 2015, "Institutional Asymmetry: How Formal and Informal Institutions Affect Entrepreneurship in Bulgaria." International Small Business Journal, 33: 840-861.

Wiśniewski, J.B., 2012, “On Regime Uncertainty and Legal Entrepreneurship.” Independent Review, 17: 253-256. 